\title{
Gonad quality of sea urchin Tripneustis gratilla with different seaweed diets
}

\section{Kualitas gonad bulubabi Tripneustis gratilla dengan pakan rumput laut yang berbeda}

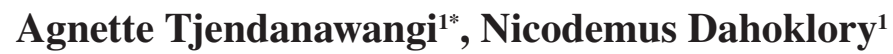 \\ ${ }^{1}$ Faculty of Fisheries and Marine Science, University of Nusa Cendana, Kupang, East Nusa Tenggara, Indonesia \\ *Corresponding author: agnette_tj@yahoo.co.id
}

(Received October 26, 2016; Accepted June 25, 2019)

\begin{abstract}
Gonad quality of sea urchin Tripneustis gratilla is influenced by consumed seaweed type. Therefore, this study was conducted to determine the type of seaweed as potential source of carotenoids and produce a good quality of sea urchin gonad. The study was conducted in two phases, namely first phase was to obtain the content of carotenoids and $\beta$-carotene from several species of seaweed; and second phase was to testify the seaweed that produced high quality of sea urchin gonad.This study used completely randomized design with 4 treatmens of macroalgae diets, namely Enhalus sp., Sargassum sp., Ulva sp., and Eucheuma sp.. Each treament was repeated three times. Measured parameters were gonad weight, gonad maturity index, gonad color quality, and gonad texture. The study result showed that Enhalus contained the highest carotenoid and $\beta$-carotene content with 1409.53 and $639.37 \mathrm{mg} /$ $\mathrm{kg}$ respectively. The highest gonad weight was $2.8 \mathrm{~g}$; gonad color and texture was good (score 3); and the highest gonad maturity index was $5.4 \%$ that obtained from sea urchin fed with Enhalus. Therefore, this study concludes that Enhalus is potential source of carotenoids for sea urchin T. gratilla diet that will produce a good quality of gonad.
\end{abstract}

Keywords: carotenoid, diet, gonad quality, sea urchin, seaweed.

\begin{abstract}
ABSTRAK
Kualitas gonad bulubabi Tripneuestes gratilla dipengaruhi oleh jenis rumput laut yang dimakan bulu babi tersebut. Oleh karena itu, penelitian dilakukan untuk menganalisis jenis rumput laut yang potensial sebagai sumber karotenoid dan dapat menghasilkan gonad yang berkualitas baik. Penelitian dilakukan dalam dua tahap, yaitu tahap I mengetahui kandungan karotenoid dan $\beta$-carotene dari beberapa jenis rumput laut; dan tahap ke II menguji jenis rumput laut yang dapat menghasilkan gonad berkualitas baik. Penelitian ini menggunakan rancangan acak lengkap yang terdiri atas empat perlakuan pakan makroalga yaitu Enhalus sp., Sargassum sp, Ulva lactuca, dan Euchema sp.. Setiap perlakuan diulang sebanyak tiga kali. Parameter yang diamati adalah bobot gobad, indeks kematangan gonad, kualitas warna, dan tekstur gonad bulubabi. Hasil penelitian menunjukkan Enhalus memiliki kandungan karotenoid dan $\beta$-carotene tertinggi masing-masing sebesar 1.409,53 dan 639,37 mg/kg. Bobot gonad tertinggi sebesar 2,8 g, warna dan tekstur gonad berkualitas baik (skor 3), serta indeks kematangan gonad (IKG) tertinggi sebesar 5,4\% dihasilkan pada pemberian pakan Enhalus. Oleh karena itu, dapat disimpulkan bahwa Enhalus potensial sebagai sumber karotenoid dalam pakan bulu babi T.gratilla dan dapat menghasilkan kualitas gonad yang baik.
\end{abstract}

Kata kunci: bulu babi, karotenoid, kualitas gonad, pakan, rumput laut 


\section{INTRODUCTION}

Tripneustes gratilla is one kind of high economical sea urchin found in Kupang Bay, East Nusa Tenggara. Sea urchin gonads are luxurious food in some Asian and Mediterranian, as well as Western countries, such as Barbados and Chile (Rahman et al., 2012; Garama et al., 2012; Elmasry et al., 2013; Elmasry et al., 2015; Rahman et al., 2014; Rahim \& Nurhasan, 2016; Cirino et al., 2017; Samuel et al., 2017). Sea urchins are also bioactive ingredient source, namely echinochrome $\mathrm{A}$, polyunsaturated fatty acids (PUFAs), $\beta$-carotene, amino acids, and EPA (Chantaro et al., 2008; Chen et al., 2010; Bragadeeswaran et al., 2013; Rahman et al., 2014).

The price of sea urchin gonad in Kupang local market ranges from $\mathrm{Rp} 10,000-15,000$ per collective sea urchin (one collective contains 10 sea urchins with 50-60 $\mathrm{mm}$ diameter). The price of sea urchin gonad in international market ranges from \$200-450 per kg (Robinson et al., 2002: Rahman et al., 2014). The gonad price depends on the gonad quality from color, flavor, texture, and gametogenesis (Feng et al., 2015). Good gonad color quality varies from the characteristics as yellow/orange color has better quality than brown/black color gonad (Phillips, 2009a; 2009b; 2009c; Garama et al., 2012).

High demand for sea urchin gonad causes this biota being continuously exploited in several countries, such as Japan, Chile, France, Canada, United States, and Colombia (Rahman et al., 2012; 2013; and 2014). The global production of sea urchin capture from 1995 to 2008 showed decreased until 32\% (FAO, 2010; Carboni et al., 2012; Rahman et al., 2014). Reduction in sea urchin supply from the nature coupled with high demand, encouraging increased sea urchin culture.

Sea urchin culture is generally directed at the production of qualified gonad based on market demand (Cirino et al., 2017). Gonad quality is influenced by several factors, namely diet type and reproductive cycle (Elmasry et al., 2015; Cirino et al., 2017; Samuel et al., 2017). Gonad quality attracted by the market is reddish yellow color, solid texture, and sweet flavor. Gonad color is determined by Echinenone and $\beta$-carotene content (Robinson et al., 2002; Garama et al., 2012). Echinenone in gonad is converted from $\beta$-carotene content in macroalgae consumed by sea urchin. Gonad texture quality is influenced by gonad maturity level. Gonad solid texture is generally produced during premature period. Gonad quality are also determined by the type of diet given and maturity level. Gonads at the final maturation or closed spawning period are usually soft with brownish and creamy color, then producig bitter taste (Tjendanawangi et al., 2014a).

Sea urchin caught from nature has various gonad quality (Garama et al., 2012; Tjendanawangi et al., 2014b). Gonad weight and quality in sea urchin Evechinus chloroticus can be modified based on the diet given and 8-12 week maintenance in cage or tank (James \& Heath, 2008; Phillips, 2009a; 2009b 2009c; Garama et $a l .$, 2012). Therefore, it is necessary to culture sea urchin with similarly good quality gonad and all time availability by determining the type of seaweed given as diet source and gonad maturity level of sea urchin. Based on this condition, this study was performed to examine different seaweed types that are potentially utilized as carotenoids and produce good quality gonad.

\section{MATERIALS AND METHOD}

\section{First phase study}

In the first phase study, ten dominant seaweed types found in sea urchin $T$. gratilla habitat at Kupang Bay, namely Padina sp., Gracilaria sp., Halymenia sp., Enhalus sp., Ulva sp., Eucheuma sp., Galaxaura sp., Halimeda sp., and Sargassum sp. Seaweed types were taken from the water, air dried, then grinded. Grinded seaweed was furtherly analyzed the total content of carotenoids, $\beta$-carotene, protein, lipid, carbohydrate, and ash. The total content of carotenoids and $\beta$-carotene were measured using spectrophotometer and HPLC (Garama et al., 2012). Seaweed protein content was measured by inhouse method, while lipid, carbohydrates, and ash content were measured by SNI 01-2891-1992 standard method.

\section{Second phase study}

This study used completely randomized design using four diet treatments. Seaweeds utilized as diet treatments were based on the high availability of $\beta$-carotene and carotenoids from the first phase, i.e Enhalus sp., Sargassum sp., Ulva sp., and Eucheuma sp. Each treatment was repeated three times.

Sea urchins T. gratilla with 50-60 mm diameter were maintained in plastic basket measuring $30 \times$ $20 \times 10 \mathrm{~cm}$. Nine plastic baskets were hung on 
three tanks measuring $2 \times 1 \times 1.5 \mathrm{~m}$ under running water system. Each tank contained three baskets and each basket was placed 10 sea urchins $T$. gratilla. Before being given diet treatment, sea urchins were adapted in the tank for one week. Sea urchins were then fasted for one week before diet treatments were given. Sea urchins were fed as much as $150 \mathrm{~g}$ every two days for six weeks maintenance.

Three sea urchins were taken to observe the gonadal development on the second, fourth, and sixth week maintenance. Measured parameters were the gonad weight, maturity index, color, and texture. Sea urchins were dissected from aboral to oral section that had no spines segment presented (interambulacral section). The inner organs were slowly removed, except the gonad attached to the shell. Furthermore, attached gonad was cleaned with water, then released from the shell using small thin spoon and placed on the filter paper. Gonad was measured to obtained the weight data. Furthermore, gonads maturity index was calculated based on:

$$
\underset{\text { index }}{\text { Gonad maturation }}=\frac{\text { Gonad weight }}{\text { Body weight }} \times 100
$$

Gonad color and texture assessment were subjectively performed by three panelists. Gonad color was compared with painted color card, then constructed based on the scoring table (Table 1) below.

\section{Data analysis}

Gonad weight and maturity index were analyzed using ANOVA. Gonad color and texture score were analyzed descriptively.

\section{RESULT}

\section{Carotenoids and $\beta$-carotene content in seaweeds}

The analysis result of total carotenoids and $\beta$-carotene content on some seaweeds indicated

Table 1. Gonad color and texture score

\begin{tabular}{cccc}
\hline Quality & Score & Color & Texture \\
\hline Very good & 4 & Light yellow or reddish orange & Solid with soft surface \\
Good & 3 & Faded yellow or orange & A bit softened with granules \\
Fairly good & 2 & Cream & Softened (easily damaged) \\
Less good & 1 & Brown & Fluid \\
\hline
\end{tabular}

Table 2. Total carotenoids and $\beta$-carotene content on some seaweeds

\begin{tabular}{ccc}
\hline Macroalgae type & Total carotenoids $(\mathrm{mg} / 1000 \mathrm{~g})$ & $\beta$-carotene $(\mathrm{mg} / 1000 \mathrm{~g})$ \\
\hline Enhalus & 1409.53 & 639.37 \\
Sargassum & 282.42 & 246.52 \\
Padina & 139.57 & 118.99 \\
Halimeda & 45.50 & $\mathrm{Nd}$ \\
Ulva & 367.06 & $\mathrm{Nd}$ \\
Euchema & 146.71 & $\mathrm{Nd}$ \\
Halymenia & 186.93 & $\mathrm{Nd}$ \\
Galaxaura & 201.71 & $\mathrm{Nd}$
\end{tabular}

Note : nd (undetected)

Table 3. Proximate analysis result on some seaweeds chosen

\begin{tabular}{cccccc}
\hline No & Macroalgae type & Protein (\%) & Lipid (\%) & Carbohydrate (\%) & Ash (\%) \\
\hline 1 & Enhalus & 12.85 & 0.56 & 45.30 & 31.72 \\
2 & Sargassum & 10.78 & 0.84 & 38.14 & 40.20 \\
3 & Ulva & 10.52 & 0.32 & 51.96 & 25.50 \\
4 & Halimeda & 15.78 & 0.32 & 41.60 & 42.25 \\
5 & Padina & 8.36 & 0.55 & 40.60 & 48.05 \\
6 & E Euchema & 16.97 & 0.55 & 38.60 & 43.32 \\
\hline
\end{tabular}


that Enhalus (seagrass) contained the highest total carotenoids and $\beta$-carotene with 1409.53 and $639.37 \mathrm{mg} / \mathrm{kg}$ respectively. The completes data were presented on Table 2.

Based on the total carotenoids and $\beta$-carotene content, seaweeds that were potentially utilized as diet source for sea urchin were Enhalus, Ulva, and Sargassum. High carotenoids and $\beta$-carotene content in seaweed can be utilized to improve the gonad color of sea urchin. The good quality of sea urchin gonad color with reddish yellow color is determined based on the echinenone content in gonad, which is converted from $\beta$-carotene in the diet (Garama et al. 2012; Vizzini et al., 2015). Furthermore, those three seaweeds are preferred by sea urchins.

\section{Proximate content}

Proximate analysis showed that six seaweeds chosen contained rangely (Table 3) 8.36-16.97 protein, $\quad 0.32-0.84 \%$ lipid, $38.6-51.96 \%$ carbohydrate, and $31.72-48.05 \%$ ash.

Low protein and lipid content indicated that seaweed is less potentially utilized as protein and lipid diet source, however potentially utilized as carbohydrate and mineral source. Low protein

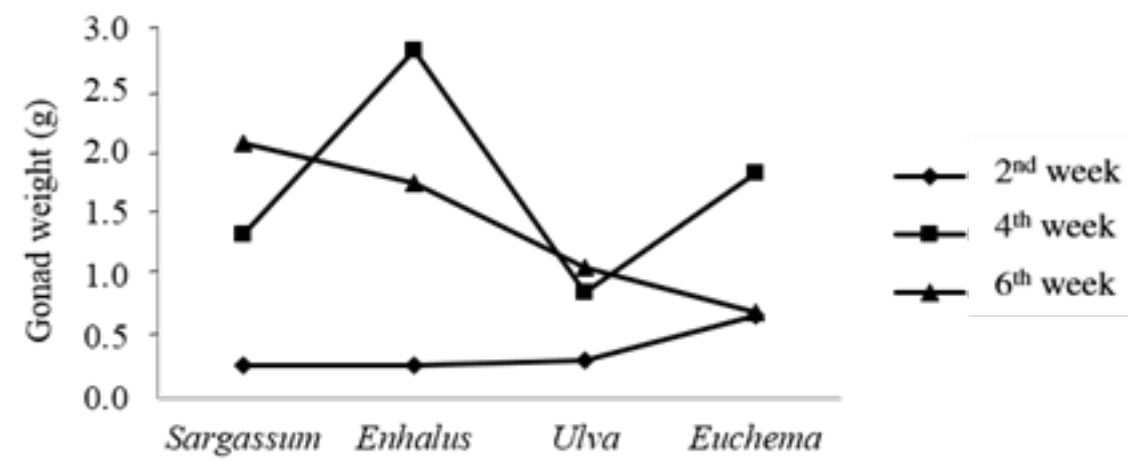

Figure 1. T. gratila gonad weight on the second until sixth week after given Sargassum, Enhalus, Ulva, and Eucheuma.

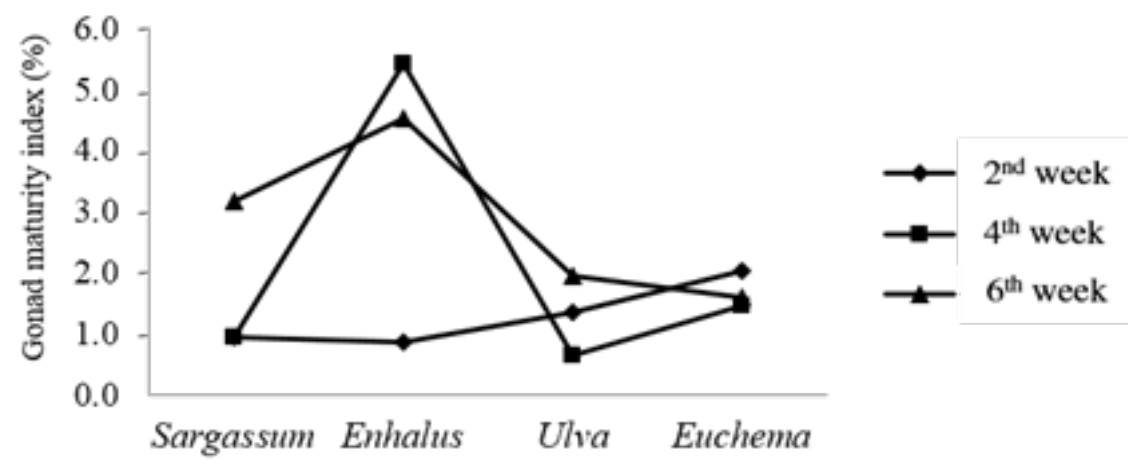

Figure 2. Gonad maturity index of T. gratila on the second until sixth week obtained from Sargassum, Enhalus, Ulva, and Eucheuma given.

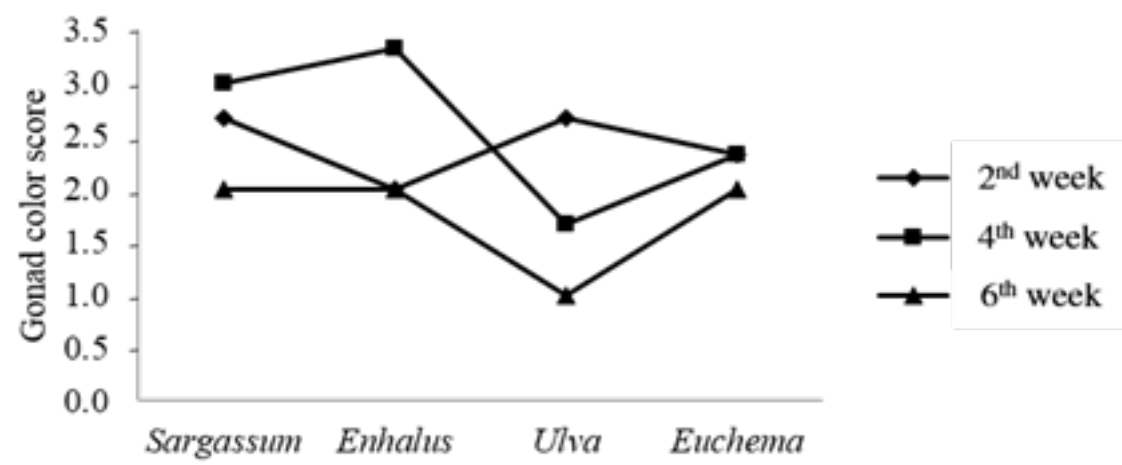

Figure 3. T. gratila gonad color on the second until sixth week after given Sargassum, Enhalus, Ulva, and Eucheuma diet. 




Figure 4. T. gratila gonad texture on the second until sixth week after given Sargassum, Enhalus, Ulva, and Eucheuma diet.

and lipid content on seaweed means that seaweed diet alone cannot be used as sea urchin diet, therefore it should be combined with other sources to increase the protein content.

\section{Gonad weight and maturity index}

Sargassum and Ulva diet given produced induced gonad weight from second to sixth week maintenance, while Enhalus and Eucheuma diet produced induced gonad weight from second to fourth week maintenance, then reduced on sixth week (Figure 1). The highest gonad weight was presented on the fourth week with $2.80 \mathrm{~g}$ after given Enhalus. The statistical analysis showed that there were insignificant difference $(\mathrm{P}>0.05)$ against the gonad weight produced after given some macroalgal type diets.

During six week maintenance, the highest gonad maturity index was obtained from the fourth week with 5.40, then reduced on the sixth week with 4.53 after given Enhalus diet (Figure 2). Sargassum, Ulva, and Eucheuma diet produced lower gonad maturity index with $\leq 3.00$. The statistical analysis obtained $\mathrm{P}>0.05$, indicating insignificant different level of gonad maturity level produced after given some macroalge types.

\section{Gonad color and texture}

The highest gonad color quality was produced from sea urchin given Enhalus and Sargassum on the fourth week with good scores (3.3 and 3.0 respectively). The lowest gonad quality was produced on the sixth week with less good score (1) after given Ulva (Figure 3).

The highest gonad texture quality was obtained from Enhalus and Sargassum diet treatment on the fourth week with good scores (3.3 and 3.0 respectively). The lowest quality was obtained on the sixth week with fairly good score (2) from Ulva diet treatment (Figure 4).

\section{DISCUSSION}

The gonad weight produced in this study was still very low compared to the gonad weight obtained from nature reaching $12 \mathrm{~g}$ (Tjendanawangi, 2014b). Gonad maturity index produced in this study was also lower than obtained from nature with $0.09-15.14$ (Tjendanawangi et al., 2010) and 3.22-12.47 (Tjendanawangi \& Dahoklory, 2011), as well as lower than Cirino et al. (2017), earning 8.70 maturity index after cultured for six weeks. This happened due to one type seaweed given on each treatment diet, whereas the sea urchin is capable of consuming various types of diet. Sartori et al. (2015) stated that diet containing maize kernel and some kind of fresh macroalgae produced $6.59 \mathrm{~g}$ gonad weight of Paracentrotus lividus with twelveth week maintenance. In addition, low gonad weight and maturity index in this study was because of low seaweed protein content $(<20 \%)$, which was inadequate to fulfill sea urchin protein requirement as sea urchin requires 20-40\% protein (Schlosser et al., 2005; Hammer et al., 2006). Gonad weight and maturiy index were influenced by nutrient contents (protein, lipid, energy) of seaweed consumed by sea urchin, besides affected by seaweed digestibility (Sartori et al., 2015) and palatability (Cyrus et al., 2015).

The reddish-yellow color of sea urchin was influenced by Echinenone as the dominant carotenoids in gonad. Echinenone is metabolized from $\beta$-carotene in diet, then transported and subsequently deposited in the gonad (Garama et al., 2012). The gonad color produced in this study achieved good quality after being given Enhalus diet containing $639.37 \mathrm{mg} / \mathrm{kg} \beta$-carotene dry weight. This result did not achieve very good quality compared to Robinson et al. (2002) on Strongylocentrotus droebachiensis who used 
Dunaliella salina microalgae with $200-250 \mathrm{mg} /$ $\mathrm{kg} \beta$-carotene dry weight. This indicated that high content of carotenoids in diet did not directly increase the gonad color quality, but it is likely influenced by the diet bioaviability consumed by sea urchin. Robinson et al. (2002) expressed the alteration of $\beta$-carotene in diet into echinenone in gonad is influenced by macroalgae consumed by sea urchins. Macroalgae as the main diet for sea urchins also contains astaxanthin, cantaxanthin, and fucoxanthin suspected to produce dark color on the sea urchin gonad (Symonds et al., 2009; Garama et al., 2012). The content of astaxanthin and fucoxanthin did not give any influences on sea urchin. Conversely, in fish and crustacean, astaxanthin might increase the gonad maturation rate, spawning, embryonal development, growth performance, and larval survival rate (Daly et al., 2013; Zhang et al., 2013).

The gonad color quality was not only influenced by carotenoids in the diet, but also maturation period and process. Tjendanawangi et al. (2010) found that very good T. gratilla gonad color quality is generally obtained during the growth phase, i.e prematuration and early maturation period, while low quality was obtained from the final maturation, spawning, and recovery period. Gonad color variation depends on the diet variation and sea urchin reproductive stage (Rahman et al., 2014).

Gonad texture quality result was in line with gonad color quality. Gonad texture was also influenced by the maturity level. When associated with gonad maturity level, the sea urchin gonad in this study reached the maturity level on the fourth week, then declined on the sixth week. Excellent color and texture gonad quality (score 4) was produced on prematuration period (Tjendanawangi et al., 2010).

\section{CONCLUSION}

Based on this study, it can be concluded that seaweed Enhalus diet is capable of producing good gonad color and texture quality of $T$. gratilla, but incapable of producing high gonad weight and maturity index.

\section{ACKNOWLEDGMENTS}

We would like to thank DP2M from Indonesian Ministry of Research, Technology, and Higher Education Affairs who had funded this study.

\section{REFERENCES}

Badan Standardisasi Nasional, 1992. Cara Uji Makanan dan Minuman SNI 01-2891-1992. Jakarta: Badan Standardisasi Nasional.

Bragadeeswaran S, Kumaran NS, Sankar PP, Prabahar R. 2013. Bioactive potential of sea urchin Temnopleurus toreumaticus from Devanampattinam, Southeast coast of India. Journal of Pharmacy and Alternative Medicine 2: 9-17.

Carboni S, Addis P, Cau A, Atack T. 2012. Aquaculture could enhance Mediterraneansea urchin fishery, expand supply. Global Aquaculture Advocate: 44-45. http:// https:// www.aquaculturealliance.org/advocate/ aquaculture-could-enhance-mediterraneansea-urchin-fishery/. [May 29, 2019].

Chantaro P, Devahastin S, Chiewchan N. 2008. Production of antioxidant high dietary fiber powder from carrot peels. LWT-Food Science and Technology 41: 1987-1994.

Chen G, Xiang WZ, Lau C, Peng J, Qiu JW, Chen F, Jiang Y. 2010. A comperative analysis of lipid and carotenoid composition of the gonads of Anthrocidaris crassispina, Diedema setosum and Salmacis sphaeroides. Food Chemistry 120: 973-977.

Cirino P, Ciaravolo M, Paglialonga A, Toscano A. 2017. Long term maintenance of the sea urchin Paracentrotus lividus in culture. Aquaculture Reports 7: 27-33.

Cyrus MD, Boluton JJ, Scholtz R, Macay BM. 2015. The advantages of Ulva (chlorophyta) as an additive in sea urchin formulated feeds: effect on palatability, consumption, and digestibility. Aquaculture Nutrition 21: 578591.

Daly B, Swingle JS, Eckert GL. 2013. Dietary astaxanthin supplementation for hatchery culture red king crab, Paralitodhes camtschaticus, juvenile. Aquaculture Nutrition 19: 312-320.

Elmasry E, Rasek FAA, Omar H, El-Magd MA. 2013. Preliminary studies on habitat and diversity of some sea urchin species (Echinodermata: Echinode) on the southern Levantine basin of Egypt. Egyption Journal of Aquatic Research 39: 303-311.

Elmasry E, Rasek FAA, El Sayed AFM, Omar H, Hamed EAE. 2015. Abudance, size composition and benthic assemblages of two Mediterranean echinoids off the Egyption coasts: Paracentrotus lividus and Arbacia 
lixula. Egyption Journal of Aquatic Research 41: 367-374.

[FAO] Food and Agriculture Organization . 2010. The State of World Fisheries and Aquaculture 2010. Rome, Italy: Food and Agriculture Organization of the United Nations.

Feng W, Yaqing C, Chong Z, Ping S, Jing W. 2015. Effect of inbreeding on growth, gametogenesis, gonad production, quality, MYP expression in the sea urchin Strongylocentrotus intermedius. Aquaculture International 23: 903-912.

Garama D, Phil B, Alan C. 2012. Extraction and analysis of carotenoids from the New Zealand sea urchin Evechinus chloroticus gonads. Biochemica Polonica 59: 83-85.

Hammer H., Watts S, Lawrence A, Lawrence J, Desmond R. 2006. The effect of dietary protein on consumption, survival, growth and production of the sea urchin Lytechinus variegatus. Aquaculture 254: 483-495.

James PJ, Heath KC. 2008. Long term roe enhancement of Evechinus chloroticus. Aquaculture 278: 89-96.

Phillips K, Niimi J, Hamid N, Silcock P, Delahunty C, Barker M, Sewell M, Bremer P. 2009a. Sensory and volatile analysis of sea urchin roe from different geographical region in New Zealand. LWT-Food Science Technology 243: 202-213.

Phillips K, Hamid N, Silcock P, Delahunty C, Barker M, Bremer P. 2009b. Effect of season on the sensory quality of sea urchin Erechinus chloroticus roe. Journal of Food Science 75: 20-30.

Phillips K, Bremer P, Silcock P, Hamid N, Delahunty C, Barker M, Kissick J. 2009c. Effect of gender, diet and storage time on ythe physical properties and sensory quality of sea urchin Erechinus chloroticus gonads. Aquaculture 288: 205-215.

Rahim SAK, Nurhasan R. 2016. Status of sea urchin resources in east coast of Borneo. Journal of Marine Biology 2016: 1-8.

Rahman MA, Amin SMN, Yusoff FM, Arshad A, Kuppan P, Shamsudin MN. 2012. Length weigth relationships and fecundity estimates of long-spined sea urchin, Diadema setosum, from the Pulau Pangkor, Peninsular Malaysia. Aquatic Ecosystem Health and Management 15: 311-315.

Rahman MA, Arshad A, Yusoff FM, Amin SMN. 2013. Hybridization and growth of tropical sea urchin. Asian Journal of Animal and Veterinary Advanced 8: 177-193.

Rahman MA, Arshad A, Yusoff FM. 2014. Sea urchin (Echinodermata: Echinodea): their biology, culture, and bioactive compounds. International Conference on Agriculture, Ecological and Medical Science (AEMS2014), July 3-4, 2014 London.

Robinson SMC, Castell JD, Kennedy EJ. 2002. Devoloping suitable colour in the gonads of cultured green sea urchine, Strongylocentrotus droebachiensis. Aquaculture 206: 289-303.

Samuel PD, Wiadnya DGR, Yanuwiadi B. 2017. Species and abundance of sea urchin on different environmental pressure condition. The Journal of Tropical Life Science 7: 146150.

Sartori D, Scuderi A, Sansone G, Gaion A. 2015. Echinoculture: the rearing of Paracentrotus lividus in recirculating aquaculture systemexperiment of artificial diets for the maintenance of sexual maturation. Aquaculture International 23: 111-125.

Schlosser SC, Lupatsch I, Lawrence JM, Lawrence AL, Sphigel M. 2005. Protein and energy digestibility and gonad development of the European sea urchin Paracetrotus lividus (Lamarck) fed algal and prepared diets during spring and fall. Aquaculture Research 36: 972-982.

Symonds R, Kelly M, Suckling C, Young A. 2009. Carotenoid in the gonad and gut of the edible sea urchin Psammechinus miliaris. Aquaculture 288: 120-125.

Tjendanawangi A, Junior MZ, Mokoginta I, Suprayudi MA, Yulianda F. 2010.Development of gonad of sea urchin Tripneustes gratilla caught in Kupang bay waters. Ichthyos 9: 7783. 
Tjendanawangi A, Dahoklory N. 2011. Studi reproduksi bulu babi Tripneuestes gratilla yang ditangkap di perairan Tablolong, Teluk Kupang. Media Exacta 12: 1310-1317.

Tjendanawangi A. 2014a. Studi biologi bulu babi Tripneuestes gratilla yang ditangkap di perairan Teluk Kupang. Media Exacta 16: 1765-1771.

Tjendanawangi A, Junior MZ, Mokoginta I, Suprayudi MA, Yulianda F. 2014b. Protein level and protein energy ratio that produce the best gonad quality of sea urchin Tripneustes gratilla. Journal of Biology and Life Science 5: 95-101.

Vizzini S, Miccichè L, Vaccaro A, Mazzola A. 2015. Use of fresh vegetable discards as sea urchin diet: effect on gonad index and quality. Aquaculture International 23: 127-139.

Zhang J, Liu YJ, Tian LX, Yang HJ, Liang GY, Yue YR, Zu DH. 2013. Effects of dietary astaxanthin on growth, antioxidant capacity, and gene expression in Pacific white shrimp, Litopenaeus vannamei. Aquaculture Nutrition 19: 917-927. 